報 文

\title{
スチレンオリゴマーの内分泌擋乱作用に関する生物学的評価
}

(平成 10 年 10 月 5 日受理)

\begin{tabular}{|c|c|c|c|}
\hline 信 原 陽 一* & 平 野 哲* & 東 幸 雅* & 伊 達 勝 廣* \\
\hline 大野克 利* & 田中和 永* & 松代創一郎* & 櫻 井 敬 展* \\
\hline 塩 澤＼cjkstart聡* & 千 葉 & 山田 敏 広* & \\
\hline
\end{tabular}

\section{Biological Evaluation of Styrene Oligomers for Endocrine-Disrupting Effects}

Yoichi Nobuhara, Satoshi Hirano, Yukimasa Azuma, Katsuhiro Date, Katsutoshi Ohno, Kazunori Tanaka, Shoichiro Matsushiro, Takanobu Sakurai, Satoshi Shiozawa, Masaru CHIBA and Toshihiro Yamada

(Central Research Institute, Nissin Food Products Co., Ltd.: 2247, Noji, Kusatsu, Shiga 525-0055, Japan)

In order to evaluate the endocrine-disrupting effects of the styrene oligomers in polystyrene, used in cups for instant noodles, we examined the effects of styrene monomer (SM), styrene dimers (SD: NSD-01, 08, 09) and styrene trimers (ST: NST-01, 02, 03) on the estrogen receptor (ER) binding assay, the androgen receptor (AR) binding assay, the proliferation of MCF-7 human breast cancer cells, the steroidogenesis in Leydig cells of rats and the uterotrophic assay of immature rats. SM, SD and ST did not significantly bind to ER or AR of rats, did not induce the proliferation of MCF-7 cells, did not inhibit testosterone production in Leydig cells of rats, and did not induce estrogen-like alteration in the uterus and vagina of immature female rats. Therefore, it appears that these SM, SD and ST have no endocrine-disrupting effects through ER, AR and steroidogenesis mechanisms.

(Received October 5, 1998)

Key words: カップ麵容器 instant noodle cup; スチレンモノマー styrene monomer; スチレンダ イマー styrene dimer; スチレントリマー styrene trimer; エストロゲン受容体 estrogen receptor; アンドロゲン受容体 androgen receptor; MCF-7 細胞 MCF-7 cells; 子宮肥大試験 uterotrophic assay

\section{緒言}

現代社会においては，人間が自然とともに人工生成物 と共存できるシステムを構築し維持することが重要な課 題となっている. 加工食品においては，特に安全な食品 を提供することが企業の使命であり, 義務であある.

最近, 河村らにより, 食品包装・容器として汎用され ているポリスチレン樹脂中に残存しているスチレンオリ ゴマーが同定され構造決定された ${ }^{1)}$. また, 材質試験及 び溶出試験の結果, これらの物質が容器から食品中に移

\footnotetext{
* 日清食品(株)中央研究所：テ525-0055 滋賀県草津市野路
} 町 2247
行する可能性も指摘された ${ }^{2), 3)}$. 一方, Colborn らは, ウイングスプレット宣言において，科学的データーは公 表されていないが，スチレンダイマー(SD) 及びスチレ ントリマー $(\mathrm{ST})$ を内分泌擋乱物質として記載してい る).

そこで著者らは, カップ麵容器の安全性確認の一環と して, 食品用ポリスチレン容器から溶出することが確認 されているスチレンオリゴマーの内分泌擋乱作用の有無 を検証するため，以下に述べる生物学的評価試験を実施 した.

内分泌擋乱作用に関する試験方法については，経済開 発協力機構 $(\mathrm{OECD})^{5)}$, 米国内分泌擋乱物質スクリー二 
<smiles>C=Cc1ccccc1</smiles>

SM

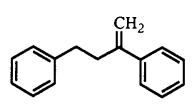

NSD-01

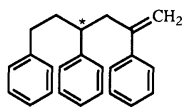

NST-01

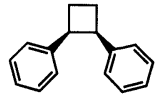

NSD-08

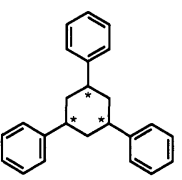

NST-02

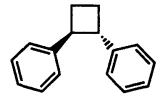

NSD-09
Fig. 1. Chemical structures of styrene monomer (SM), styrene dimers (NSD-01, NSD08 and NSD-09), and styrene trimers (NST-01, NST-02 and NST-03)

ング及び試験諮問機関 (EDSTAC) $)^{6}$ 及び厚生省内分泌擋 乱化学物質の健康影響に関する検討会7)などの各機関で 検討中であり, 現在, 試験方法に関する試案が報告され ている．著者らは，それら試案に準拠して，エストロゲ ン受容体 $(\mathrm{ER})$ 結合試験, アンドロゲン $(\mathrm{AR})$ 受容体結 合試験, ヒト乳ガン細胞 MCF-7 増殖試験, 精巣細胞ス テロイドホルモン生合成試験及び幼若ラット子宮肥大試 験を実施した。

被験物質は, 河村らにより一部カップ麵容器から溶出 することが確認されている2,3) SD 及び ST について当 社研究所において化学的に合成, 市販のスチレンモノ マー (SM) ととあに試験に供した.

その結果, それらの物質の安全性を確認しうる試験結 果を得たので報告する.

\section{実験方法}

\section{1. 被験物 質}

ポリスチレン製造中の副生成物，熱などの強制分解生

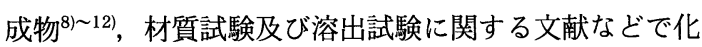
学構造式の提出 ${ }^{1), 21,13)}$ されている SD及び ST の標準品 を合成した ${ }^{14)}$. その内, 材質試験で確認される（検出限 界 $1 \mu \mathrm{g} / \mathrm{g})$ あのは, SD3 検体, ST2 検体であった (Fig. 1). 溶出試験で確認された化学物質は, 材質試験 のものと同様であり, 新たな化合物が溶出してくること はなく14)，河村らによって報告されているあの1), 2) と同 一であった. そこで, 内分泌擋乱作用の有無を検証する
被験物質を Fig. 1 に示した 5 検体及び河村ら ${ }^{1)}$ にっ て溶出するとされるNSD-02 を加えた, 計 6 検体とし, 核磁気共鳴, 質量分析, 元素分析で化学構造を確認した (Table 1). また，それらの純度は GC-FIDによりすべ て 98.5\% 以上であり, NST-01 はラセミ体であった. NST-02 はメソ体である NST-02-1 と NST-02-2 の混合 物であり, その混合比は $7: 5$ である. NST-03 あ光学 不活性な 4 種類のジアステレオマーの混合物で, それ らの構造を合成的系路によって分離することにより確認 した.また，GC-FIDによる保持時間の小さい順に NST-03-1, NST-03-3, NST-03-2, NST-03-4 とした場 合, それらのピーク強度比は $3: 4: 2: 1$ であった.

被験物質の物理化学的データは, 磁気核共鳴装置: JEOL JNM-GSX400（日本電子社製），融点装置：MP500D (ヤナコ社製), 元素分析装置：MT-5（ヤナコ社 製), ガスクロマトグラフ質量分析装置：JEOL AX505 H (日本電子社製)，ガスクロマトグラム：GC-15A（島 津製作所社製) を用いて測定を行った.

\section{2. 試薬}

$\mathrm{SM}$ はナカライテスク (株) 製, (Fig. 1), ビスフェ ノール A, $p$-ノニルフェノールは東京化成(株)製, エス トラジオール $17 \beta\left(\mathrm{E}_{2}\right)$, ジェチルスチルベストロール (DES), フルタミド, 酢酸シプロテロン, トリアムシノ ロンアセトニド，大豆トリプシンインヒビター (STI), ヒト䄉毛性性腺刺激ホルモン (hCG), ケトコナゾールは Sigma 社製, ジヒドロテストステロン (DHT) は和光純 薬(株)製, $\left[2,4,6,7-{ }^{3} \mathrm{H}(\mathrm{N})\right]$ エストラジオール $\left(\left[{ }^{3} \mathrm{H}\right] \mathrm{E}_{2}\right)$, $\left[17 \alpha\right.$-メ チ ル- $\left.{ }^{3} \mathrm{H}\right]$ ミボレロン $\left(\left[{ }^{3} \mathrm{H}\right] \mathrm{MIB}\right), \mathrm{MIB}$ は DuPont NEN 社製, ダルベッコ改変イーグル (DME) 培地, M199 培地, 牛胎児血清 (FBS), ウシ血清アルブ ミン (BSA) は Gibco BRL 社製を用いた. テストステ ロン EIA キットは Cayman 社製を用いた。 その他の試 薬は, 市販特級品あるいは, HPLC 用を用いた.

緩衝液 $\mathrm{E}: 10 \mathrm{mmol} / \mathrm{L}$ Tris-HCl, $1.5 \mathrm{mmol} / \mathrm{L}$ EDTA, $10 \mathrm{mmol} / \mathrm{L}$ thioglycerol, $10 \%$ glycerol, $10 \mathrm{mmol} / \mathrm{L}$ $\mathrm{NaMoO}_{4}(\mathrm{pH}$ 7.4)

緩衝液 A: $10 \mathrm{mmol} / \mathrm{L}$ Tris- $\mathrm{HCl}, 1.5 \mathrm{mmol} / \mathrm{L}$ EDTA, $1 \mathrm{mmol} / \mathrm{L}$ DTT, $10 \mathrm{mmol} / \mathrm{L} \mathrm{NaMoO}_{4}(\mathrm{pH} 7.4)$

\section{3. 使用動物}

Sprague-Dawley (SD) 系ラットを日本チャールス・ リバー(株)から購入し, 試験に供した. ラットの飼育 は, SPF 飼育施設にて室温 $23.5 \pm 2{ }^{\circ} \mathrm{C}$, 湿度 $55 \pm 10 \%$, 照明時間 12 時間 $(8: 00 \sim 20: 00)$ の条件下で行った。

\section{4. エストロゲン受容体結合試験}

Krishnan らの方法 ${ }^{15)}$ に準拠して行った. 7 週歯の $\mathrm{SD}$ 系雌性ラット $(170 \sim 190 \mathrm{~g})$ の卵巣を摘出し，2 日 間飼育した。

子宮を摘出し, 緩衝液 $\mathrm{E}$ 中で $1 \mathrm{~g} / 4 \mathrm{~mL}$ の割合で破 砕した．破砕液を $110,000 \times g, 4^{\circ} \mathrm{C}$ で 1 時間遠心分離 


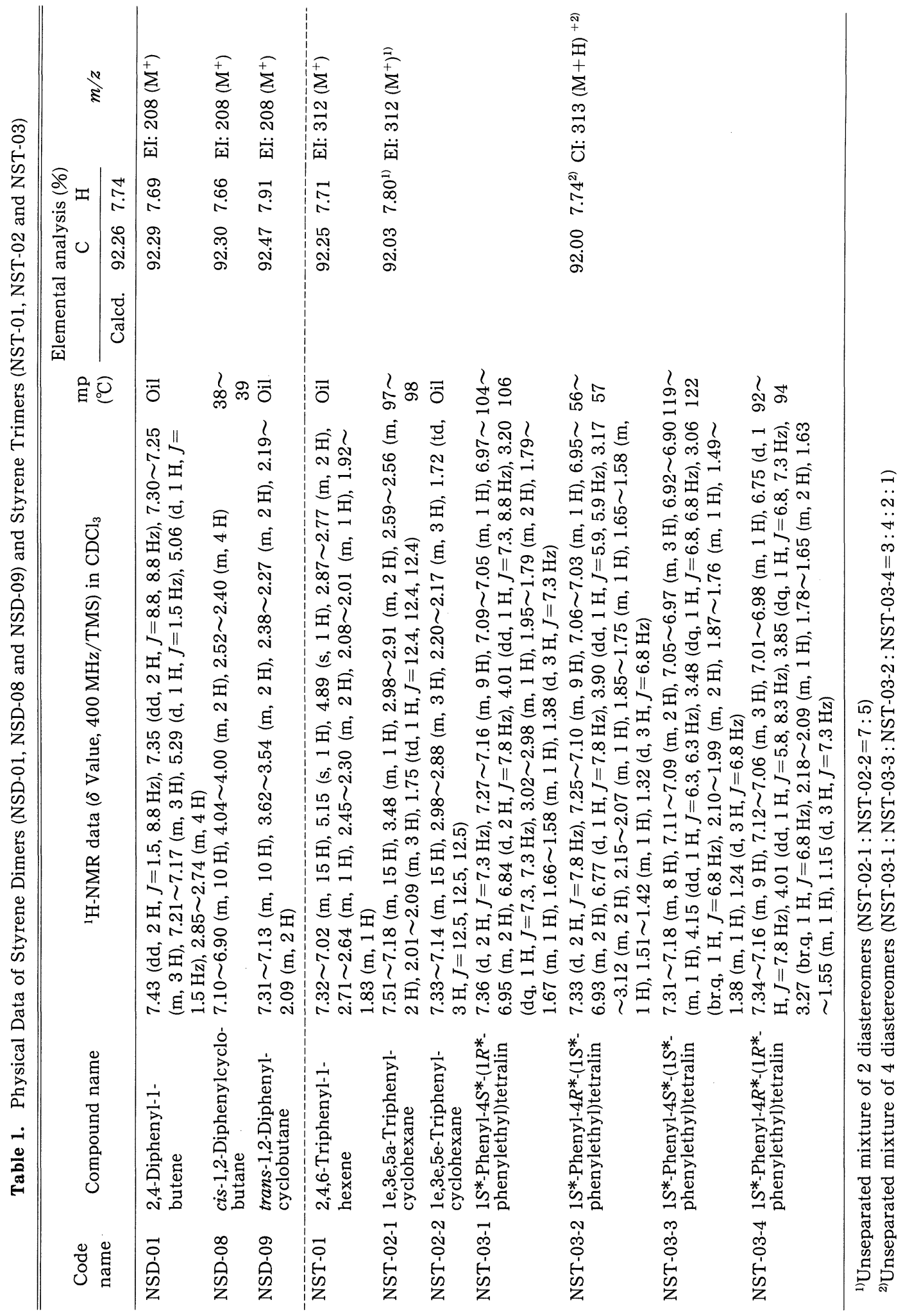



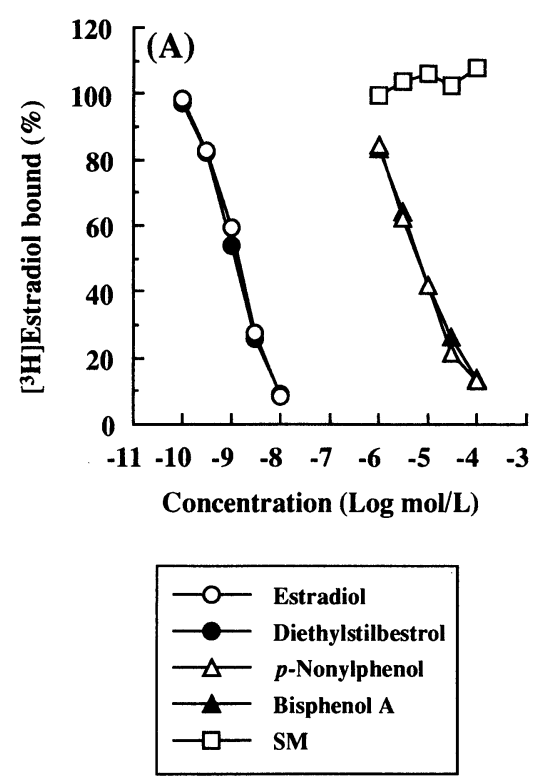
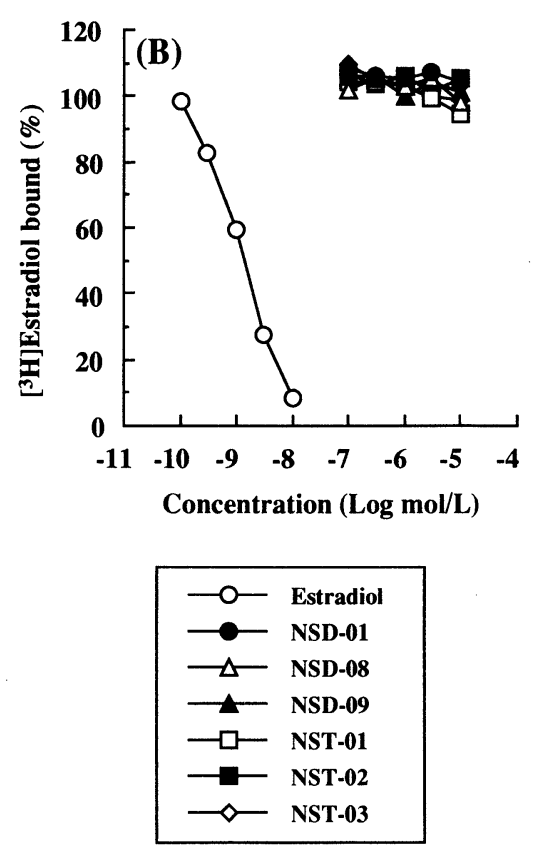

Fig. 2. Estrogen receptor binding assay of styrene monomer (SM) (A), styrene dimers (NSD-01, NSD-08, NSD-09) and styrene trimers (NST-01, NST-02, NST-03) (B)

Rat uterine cytosol was incubated with $1 \mathrm{nmol} / \mathrm{L}$ of $\left[{ }^{3} \mathrm{H}\right]$ estradiol and test compounds. After incubation for $18 \mathrm{hr}$ at $0^{\circ} \mathrm{C}$, the receptor was separated by Norit A-Dextran T-70 and the radioactivity was counted. Each value represents the mean of duplicate assays.

し，得られた上清を細胞質画分（ER 画分）として使用 した. ラット子宮細胞質画分 $20 \mu \mathrm{L}, 1 \mathrm{nmol} / \mathrm{L}\left[{ }^{3} \mathrm{H}\right] \mathrm{E}_{2}$ 及び被験物質を含む緩衝液 $\mathrm{E} よ り$ 成る反応液 $(0.2 \mathrm{~mL})$ を $0^{\circ} \mathrm{C}$ で 18 時間インキュベートした. 被験物質はジメ チルスルホキシド（DMSO: 最終濃度 $0.2 \%$ ）に溶解さ せて反応液に添加した. 反応液に $0.5 \%$ Norit A 及び 0.05\% Dextran T-70 の混合液 $0.2 \mathrm{~mL}$ を添加し, 更に $0^{\circ} \mathrm{C}$ で 10 分間インキュベートした. その後, $1,000 \times g$, $4^{\circ} \mathrm{C}$ で 10 分間遠心分離し, 得られた上清の放射活性を 液体シンチレーションカウンターで测定した. $\left[{ }^{3} \mathrm{H}\right] \mathrm{E}_{2}$ の ER 結合に対する被験物質の拮抗阻害活性により受容 体結合性を評価し，その力価を $50 \%$ 抑制濃度 $\left(\mathrm{IC}_{50}\right.$ 值）で表示した.

\section{5. アンドロゲン受容体結合試験}

Dalton らの方法 ${ }^{16)}$ に準拠して行った. 7 週齢 SD系 雄性ラット $(220 \sim 250 \mathrm{~g})$ を去勢し，24 時間後に前立 腺を摘出, 緩衝液 $\mathrm{A}$ 中で $1 \mathrm{~g} / 2 \mathrm{~mL}$ の割合で破砕した. 破砕液を $110,000 \times \mathrm{g}, 4^{\circ} \mathrm{C}$ で 1 時間遠心分離し, 得ら れた上清を細胞質画分（AR 画分）として使用した. ラット前立腺細胞質画分 $20 \mu \mathrm{L}, 2 \mathrm{nmol} / \mathrm{L}\left[{ }^{3} \mathrm{H}\right] \mathrm{MIB}, 1$ $\mu \mathrm{mol} / \mathrm{L}$ トリアムシノロンアセトニド及び被験物質を含 む緩衝液 $\mathrm{A}$ より成る反応液 $(0.2 \mathrm{~mL})$ を $0{ }^{\circ} \mathrm{C}$ で 18 時間
インキュベートした. 被験物質はDMSO（最終濃度 $0.2 \%$ ）に溶解させて反応液に添加した. 反応液に 0.5\% Norit A 及び $0.05 \%$ Dextran T-70 の混合液 0.2 $\mathrm{mL}$ を添加し, 更に $0^{\circ} \mathrm{C}$ で 10 分間インキュベートし た. その後, $1,000 \times g, 4^{\circ} \mathrm{C}$ で 10 分間遠心分離し, 得 られた上清の放射活性を液体シンチレーションカウン ターで測定した. $\left[{ }^{3} \mathrm{H}\right] \mathrm{MIB}$ の AR 結合に対する被験物 質の拮抗阻害活性により受容体結合性を評価し, その力 価を $50 \%$ 抑制濃度 ( $\mathrm{IC}_{50}$ 值) で表示した.

\section{6. ヒト乳ガン細胞 MCF-7 増殖試験}

ヒト乳ガン細胞株 MCF-7 は大日本製薬(株)より購入 した. 5\% FBS 添加 DME 培地で, $37^{\circ} \mathrm{C}, 5 \%$ 二酸化炭 素, 飽和湿度中で継代培養を行った.

増殖試験は, Soto らの方法 ${ }^{17)}$ に従った. MCF-7 細胞 を 12 well plate に播種し $\left(2.0 \times 10^{4}\right.$ cells/well), $5 \%$ FBS 添加 DME 培地 $1 \mathrm{~mL}$ 中で 24 時間培養した. 培地 を被験物質を含む $5 \%$ 活性炭処理ヒト血清添加 DME 培地（フェーノールレッド不含） $1 \mathrm{~mL}$ に交換して 6 日 間培養した後, 細胞数を計測した. 被験物質はエタノ一 ル（最終濃度 $0.1 \%$ ）に溶解させて培地に添加した。 

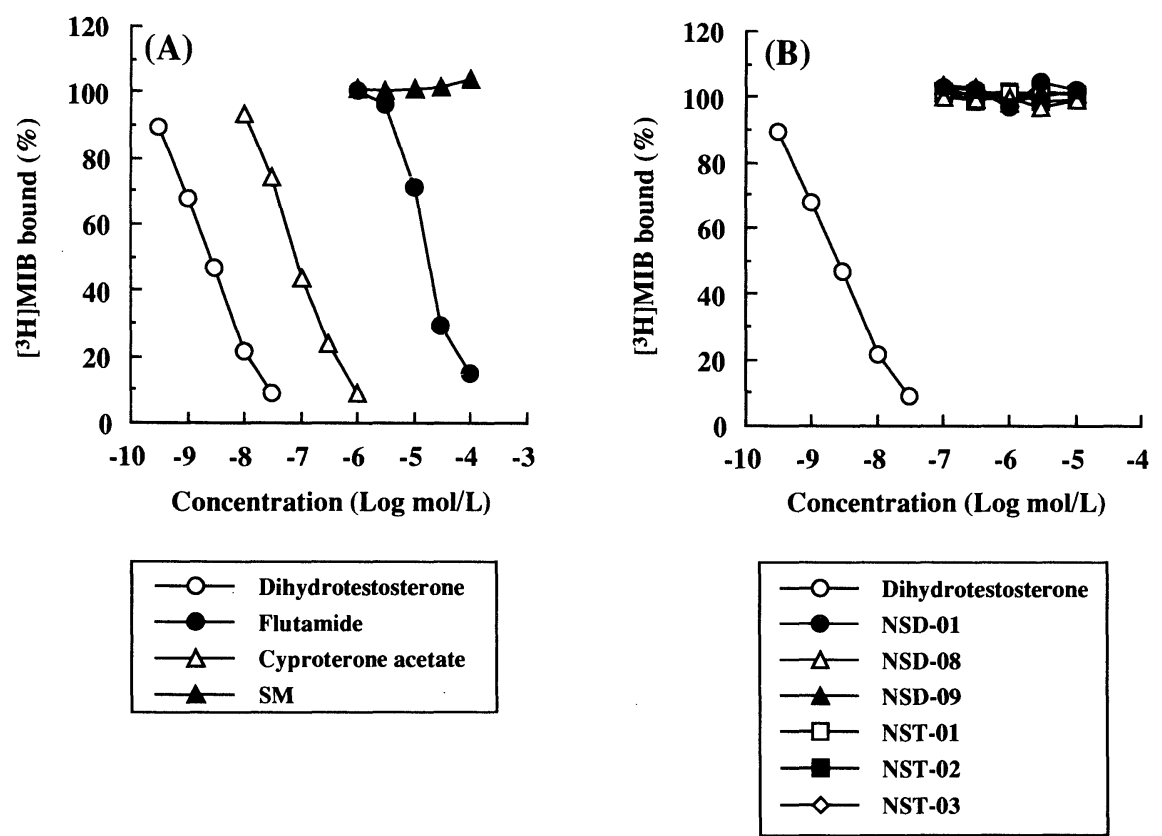

Fig. 3. Androgen receptor binding assay of styrene monomer (SM) (A), styrene dimers (NSD-01, NSD-08, NSD-09) and styrene trimers (NST-01, NST-02, NST-03) (B)

Rat prostatic cytosol was incubated with $2 \mathrm{nmol} / \mathrm{L}$ of $\left[{ }^{3} \mathrm{H}\right]$ mibolerone (MIB) and test compounds. After incubation for $18 \mathrm{hr}$ at $0^{\circ} \mathrm{C}$, the receptor was separated by Norit A-Dextran T-70 and the radioactivity was counted. Each value represents the mean of duplicate assays.

\section{7. 精巣細胞ステロイドホルモン生合成試験}

Klinefelter らの方法 ${ }^{18)}$ に準拠して行った. 7 週齢の $\mathrm{SD}$ 系雄性ラット $(230 \sim 240 \mathrm{~g})$ の精巣の白膜を除き, $0.25 \mathrm{mg} / \mathrm{mL}$ コラゲナーゼを含む $0.1 \% \mathrm{BSA}$ 及び $0.0025 \%$ STI 添加 M199 培地中, $37^{\circ} \mathrm{C}$ で 20 分間振盪 処理 $(90 \mathrm{rpm})$ した．等量の $0.1 \%$ BSA 及び $0.0025 \%$ STI 添加 M199 培地を加えた後, ろ過, 遠心分離によ り精巣間質細胞を得た．この間質細胞にはテストステロ ン合成を行うライディッヒ細胞が約 $14 \%$ 含まれてい る ${ }^{11)}$. 間質細胞を 24 well plate に播種し $\left(2.0 \times 10^{6}\right.$ cells/well), 被験物質を含む $0.1 \%$ BSA 及び $0.0025 \%$ $\mathrm{STI}$ 添加 M199 培地 $1 \mathrm{~mL}$ 中, $37^{\circ} \mathrm{C}, 5 \%$ 二酸化炭素, 飽和湿度の条件下で 1 時間培養した後, hCG を 0.1 $\mathrm{IU} / \mathrm{mL}$ 添加し, 更に 3 時間培養した. 被験物質は DMSO（最終濃度 $0.2 \%$ ）に溶解させて反応液に添加し た.

培養上清を採取し, テストステロン濃度を EIA 法で 定量した.

\section{8. 幼若ラット子宮肥大試験}

Odum らの方法 ${ }^{19)}$ に準拠して行った. 21 日齢の雌性 ラット $(40 \sim 50 \mathrm{~g})$ にコーン油に溶解した被験物質を 1 日 1 回，3 日間連続皮下投与した. 最終投与の 24 時間
後に子宮及び腔を摘出し, 子宮の湿重量を測定した。 そ の後, 子宮及び膣を中性緩衝ホルマリンで固定し, パラ フィンブロックを作製した．これを薄切し，ヘマトキシ リン・エオジン染色を行った後, 子宮及び腔粘膜上皮細 胞の病理組織学的検査を実施した.

\section{統計処理}

数值結果は平均値士標準偏差で表示した，統計学的有 意差検定は, 2 群間では分散分析検定後, 等分散の場合 はStudent's $t$-検定を，不等分散の場合はAspinWelch 検定を用いた. 多群間では Dunnett の多重比較 検定を用いた。いずれも $p<0.05$ の場合を有意差ありと 判定した.

\section{実 験 結果}

\section{1.エストロゲン受容体結合試験}

結果を Fig. 2 に示した. $\mathrm{E}_{2}$ 及び合成エストロゲンで ある DES は，濃度依存的に $\left[{ }^{3} \mathrm{H}\right] \mathrm{E}_{2}$ の $\mathrm{ER}$ への結合を阻 害し, $\mathrm{IC}_{50}$ 值が 1.41 及び $1.29 \mathrm{nmol} / \mathrm{L}$ と強力な $\mathrm{ER}$ 結 合性を示した. エストロゲン様作用が報告されている $p$-ノニルフェノール ${ }^{20)}$ 及びビスフェノール $\mathrm{A}^{21)}$ は, $\mathrm{E}_{2}$ に比べると作用は弱いものの濃度依存的に $\left[{ }^{3} \mathrm{H}\right] \mathrm{E}_{2}$ の $\mathrm{ER} へ$ 結合を阻害し，それらの $\mathrm{IC}_{50}$ 值は 7,060 及び $7,440 \mathrm{nmol} / \mathrm{L}$ であった。これに対し, SM は 100 


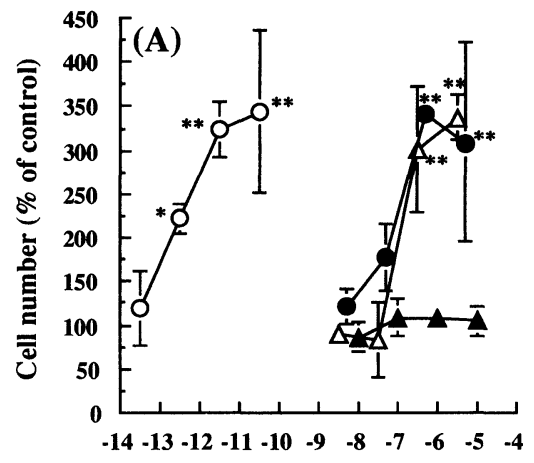

Concentration $(\log \mathrm{mol} / \mathrm{L})$

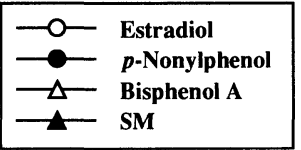

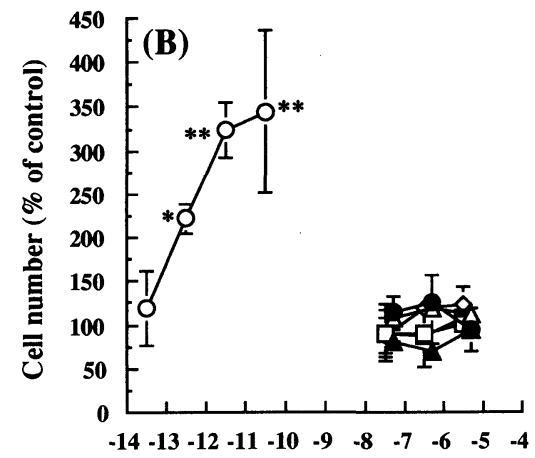

Concentration $(\log \mathrm{mol} / \mathrm{L})$

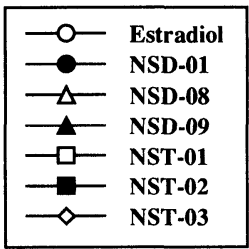

Fig. 4. Effects of styrene monomer (SM) (A), styrene dimers (NSD-01, NSD-08, NSD-09) and styrene trimers (NST-01, NST-02, NST-03) (B) on proliferation of MCF-7 cells

The cells were treated with test compounds for 6 days, as described in Methods.

$*$ **: $p<0.05,0.01$ (vs. Control). Each value represents the mean $\pm \mathrm{SD}$ ( $n=3$ wells).

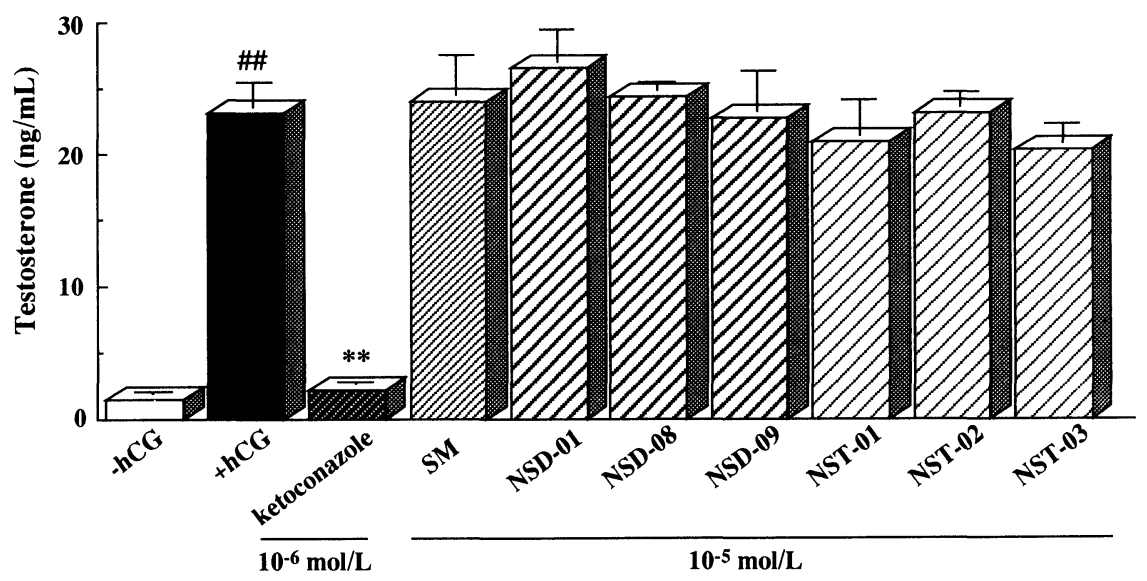

Fig. 5. Effects of styrene monomer (SM), styrene dimers (NSD-01, NSD-08, NSD-09) and styrene trimers (NST-01, NST-02, NST-03) on hCG stimulated testosterone production by Leydig cells of rats

Testicular interstitial cells containing Leydig cells were incubated with test compounds for $1 \mathrm{hr}$ followed by the addition of $0.1 \mathrm{IU} / \mathrm{mL}$ hCG to the assigned wells. After incubation for $3 \mathrm{hr}$, culture media were removed and analyzed for testosterone concentrations by EIA. \#\#: $p<0.01$ (vs. $-\mathrm{hCG}$ ), **: $p<0.01$ (vs. + hCG). Each value represents the mean $\pm \mathrm{SD}$ ( $n=3$ wells).

$\mu \mathrm{mol} / \mathrm{L}$ まで, 被験物質は可溶化上限濃度である 10 $\mu \mathrm{mol} / \mathrm{L}$ まで $\left[{ }^{3} \mathrm{H}\right] \mathrm{E}_{2}$ の $\mathrm{ER}$ 結合に対し阻害作用を示さ ず， $\mathrm{IC}_{50}$ 值を求めることはできなかった。 したがって,
$\mathrm{SM}$ 及び被験物質には ER 結合性は認められなかった.

\section{2. アンドロゲン受容体結合試験}

結果を Fig. 3 に示した. DHT は濃度依存的に $\left[{ }^{3} \mathrm{H}\right]$ 

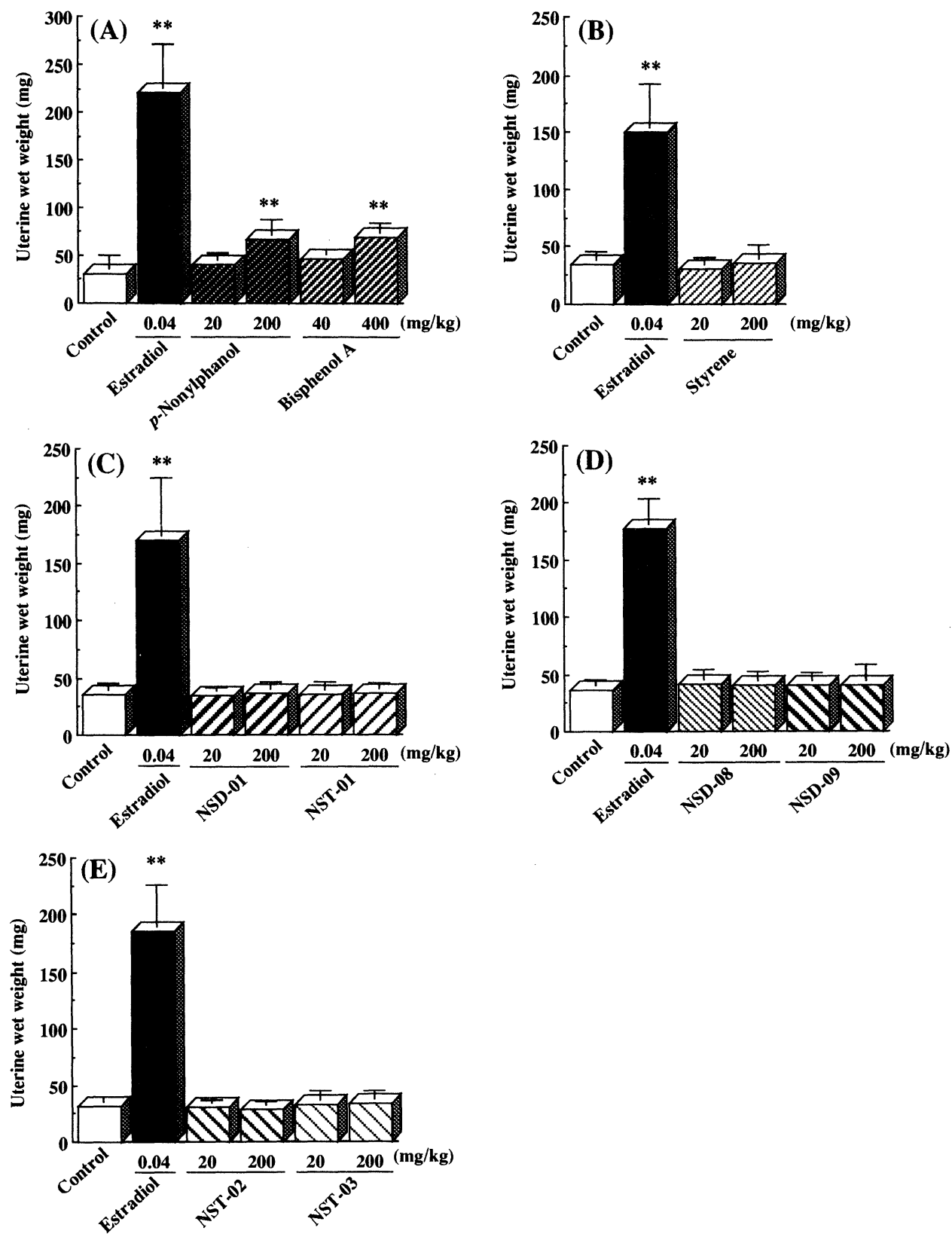

Fig. 6. Effects of styrene monomer (SM), styrene dimers (NSD-01, NSD-08, NSD-09) and styrene trimers (NST-01, NST-02, NST-03) on uterus wet weight in immature rats Immature rats were treated subcutaneously with each test compounds dissolved in corn oil for 3 days. After $24 \mathrm{hr}$ of final treatment, uteri and vaginae were removed and uteri were weighed. $* *$ : $p<0.01$ (vs. Control). Each value represents the mean \pm $\mathrm{SD}(n=5)$.

$\mathrm{MIB}$ の $\mathrm{AR}$ の結合を阻害しそこの $\mathrm{IC}_{50}$ 值は 3.40 $\mathrm{nmol} / \mathrm{L}$ であった.

AR アンタゴニストであるフルタミド22) 及び酶酸シプ
ロテロン22) は，DHT に比べると作用は弱いものの濃度 依存的に $\left[{ }^{3} \mathrm{H}\right] \mathrm{MIB}$ の AR への結合を阻害し，それらの $\mathrm{IC}_{50}$ 值は 22,300 及び $97.1 \mathrm{nmol} / \mathrm{L}$ であった。これに 
Table 2. Summary of the Effects of Styrene Monomer (SM), Styrene Dimers (NSD-01, NSD-08, NSD-09) and Styrene Trimers (NST-01, NST-02, NST-03) on Immature Rat Uterotrophic Assay

\begin{tabular}{|c|c|c|c|c|}
\hline \multirow[b]{2}{*}{ Compound } & \multirow{2}{*}{$\begin{array}{c}\text { Dose } \\
(\mathrm{mg} / \mathrm{kg})\end{array}$} & \multirow{2}{*}{$\begin{array}{c}\text { Increase of } \\
\text { uterine weight }\end{array}$} & \multicolumn{2}{|c|}{ Histopathological evaluation } \\
\hline & & & $\begin{array}{l}\text { Hypertrophy of uterine } \\
\text { luminal epitherium }\end{array}$ & $\begin{array}{l}\text { Cornification of } \\
\text { vaginal mucosa }\end{array}$ \\
\hline Control & & & - & - \\
\hline Estradiol & 0.04 & +++ & + & + \\
\hline \multirow[t]{2}{*}{ p-Nonylphenol } & 20 & - & - & - \\
\hline & 200 & ++ & + & + \\
\hline \multirow[t]{2}{*}{ Bisphenol A } & 40 & - & - & - \\
\hline & 400 & ++ & + & + \\
\hline \multirow[t]{2}{*}{$\mathrm{SM}$} & 20 & - & - & - \\
\hline & 200 & - & - & - \\
\hline \multirow[t]{2}{*}{ NSD-01 } & 20 & - & - & - \\
\hline & 200 & - & - & - \\
\hline \multirow[t]{2}{*}{ NSD-08 } & 20 & - & - & - \\
\hline & 200 & - & - & - \\
\hline \multirow[t]{2}{*}{ NSD-09 } & 20 & - & - & - \\
\hline & 200 & - & - & - \\
\hline \multirow[t]{2}{*}{ NST-01 } & 20 & - & - & - \\
\hline & 200 & - & - & - \\
\hline \multirow[t]{2}{*}{ NST-02 } & 20 & - & - & - \\
\hline & 200 & - & - & - \\
\hline \multirow[t]{2}{*}{ NST-03 } & 20 & - & - & - \\
\hline & 200 & - & - & - \\
\hline
\end{tabular}

$+:$ Positive test results, relative levels of effects are indicated by number of.+- : Negative test results.

対し, SM は $100 \mu \mathrm{mol} / \mathrm{L}$ まで, 被験物質は可溶化上 限濃度である $10 \mu \mathrm{mol} / \mathrm{L}$ まで $\left[{ }^{3} \mathrm{H}\right] \mathrm{MIB}$ の AR 結合に 対し阻害作用を示さず， $\mathrm{IC}_{50}$ 值を求めることはできな かった．したがって，SM 及び被験物質には AR 結合性 は認められなかった。

\section{3. ヒト乳ガン細胞 MCF-7 増殖試験}

結果を Fig. 4 に示した. MCF-7 細胞は $0.03 〜 30$ $\mathrm{nmol} / \mathrm{L}$ の $\mathrm{E}_{2}$ 添加により約 4 倍に増殖した. $p$-ノニル フェノール及びビスフェノール A あ MCF-7 細胞を増 殖させたが，その作用は $\mathrm{E}_{2}$ と比較して約 17,000 及び 約 100,000 倍弱いあのであった。これに対し, SM及 び被験物質には明らかな増殖刺激性は認められなかっ た.

\section{4. 精巣細胞ステロイドホルモン生合成試験}

結果を Fig. 5 に示した. ラット精巣ライディッヒ細 胞のテストステロン産生量は $\mathrm{hCG}$ 刺激により約 17 倍 に増加した. これに対し, 対照物質として用いたケトコ ナゾールは，いくつかのステロイド合成酵素（P450酵 素）活性を抑制し，ライディッヒ細胞のテストステロン 産生を阻害することが報告されている ${ }^{23)}$ が, $1 \mu \mathrm{mol} / \mathrm{L}$ の濃度でほぼ完全に hCG 刺激テストステロン合成を阻 害した。一方，SM及び被験物質は $10 \mu \mathrm{mol} / \mathrm{L}$ におい てライディッヒ細胞の hCG 刺激テストステロン合成を
有意に抑制しなかった.

\section{5. 幼若ラット子宮肥大試験}

結果を Fig. 6 及び Table 2 に示した. 幼若ラット子 宮重量は $40 \mu \mathrm{g} / \mathrm{kg} \mathrm{E} \mathrm{E}_{2}$ の 3 日間投与により顕著に増加 した. 対照物質として用いた $p$-ノニルフェノール及び ビスフェノール A 投与群では, 各々 200 及び $400 \mathrm{mg} /$ $\mathrm{kg}$ において有意な子宮重量の増加が認められた. これ に対し, SM 及び被験物質投与群（20及び $200 \mathrm{mg} /$ $\mathrm{kg}$ ）には有意な子宮重量増加作用は認められなかった.

一方, 病理組織学的検査において, $\mathrm{E}_{2}$ 投与群では子 宮内膜上皮 (luminal epithelium) の顕著な肥厚及び上 皮細胞の高円柱化が認められた. また, 臸では粘膜上皮 の角化形成が認められた. $p$-ノニルフェノール及びビス フェノール A 投与群においてあ同様な変化が子宮及び 腔粘膜において認められた。これに対し，SM 及び被験 物質投与群にはいずれもこのような変化は観察されな かった.

\section{考察}

食品包装容器の安全性の確保は, 食品そのものと同 様, 食生活にとって重要な課題である. とりわけ食品用 プラスチック製の容器に使用される材質については, 食 品衛生法（第 $8,9,10$ 条）が適用され, その規格と基 準が定められている. カップ麵用ポリスチレンに関して 
は, 熱湯を用いるあのとして材質中の総揮発分 2,000 ppm 以下，スチレンモノマー $1,000 \mathrm{ppm}$ 以下，エチ ルベンゼン $1,000 \mathrm{ppm}$ 以下と規制されており, 現在市 販されている製品は，すべてこの規格に適合した製品で ある.

最近, 河村らにより, カップ麵用ポリスチレン容器材 質中に，スチレンオリゴマーが残存していることが指摘 され1), 溶出試験の結果から,これらの物質が容器から 食品中に移行する可能性む指摘された ${ }^{2), 3)}$. 一方, Colborn らは，科学的データーは公表されていないが，SD 及び ST を内分泌擋乱作用の疑いのある物質としてリス トに記載している ${ }^{4)}$ そここで著者らは，ポリスチレン容 器素材中に存在し, 一部カップ麵容器から溶出すること が確認され, 構造決定されている SD 及び ST を生物学 的評価の対象物質とし，それらを化学的に合成すること により，内分泌擋乱作用の有無を検証した.

まず，ホルモン受容体レベルの検討において，SM 及

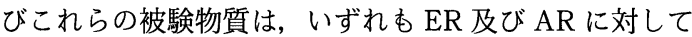
結合性を示さなかった. レセプター理論において，「結 合無きところに作用無し」と言われるように，これらの 結果は，上記の物質が $\mathrm{ER}$ 及び AR に対しアゴニストに あアンタゴニストにもなりえないことを示しており，こ れらの性ホルモン作用に影響を及ぼさないことが強く示 唆された。 また，ER及び AR は，エストロゲンの標的 組織（子宮，腔，卵管，乳腺）及びアンドロゲンの標的 組織（前立腺，精囊腺）の他，視床下部，脳下垂体前葉 にも高濃度に分布し，ホルモン生合成のフィードバック 機構を構成している. したがって, 本試験に用いた SM 及び被験物質は，これらの受容体を介した性ホルモン フィードバック系に対してあ影響を与えないことが示唆 された.

次に, Soto らの方法 ${ }^{17)}$ に準拠して実施した細胞レベ ルの検討，すなわちヒト乳ガン細胞 MCF-7 増殖試験に おいて，SM 及び被験物質は増殖作用を示さなかった。 対照物質として用いたp-ノニルフェノール及びビス フェノール A は高濃度ではあるが明らかな増殖作用を 示した. SM が MCF-7 に対して増殖活性を有さないこ

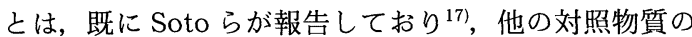
結果も既報 ${ }^{17), 20)}$ を支持するあのである．以上の結果は， 本試験に用いた SM 及び被験物質がエストロゲン様作 用を有さないことを細胞レベルで証明したものであり，

$\mathrm{ER}$ 結合試験の結果を強く支持するあのである。

次に，受容体を介さない内分泌擋乱作用の可能性とし て，ホルモン生合成系への影響も指摘されている。テス トステロンのほか, $\mathrm{E}_{2}$ を含むエストロゲン, 糖質コル チコイド，鉱質コルチコイドなどのステロイドホルモン の生合成経路は重複しており, チトクロム P450酵素群 に担われている，特にエストロゲンはテストステロンか ら形成される。このような理由から，EDSTAC はその
試案の中でステロイド生合成アッセイ系として，培養精 单又は単離した精巣ライディッヒ細胞を用いてテストス テロン産生への影響を検討する方法を提案している 本研究では, Kleinfelter らの方法 ${ }^{18)}$ に準拠してラット 精巣よりライディッヒ細胞を含む間質細胞画分を調製 し, hCG 刺激テストステロン産生に対する検討を行っ た。その結果，SM 及び被験物質はいずれあ有意な作用 を示さなかった。 これらの結果から, 被験物質がテスト ステロン産生のみならず，ステロイドホルモン生合成系 に影響を与えないことが示唆された。

最後に，実験動物レベルの試験として幼若ラット子宮 肥大試験を実施した。宮肥大試験には生後 21 日齢の 性的未成熟ラットを用いる方法と，卵巣摘出した成熟 ラットを用いる方法が報告されている．Cook らは卵巣 摘出成熟ラットに $\mathrm{E}_{2}$ を 4 日間腹腔内投与した場合，子 宮重量増加，内膜肥厚などの变化を観察し，内分泌擋乱 化学物質の疑いのあるビスフェノール A を高用量投与 した場合もこのような作用を示したと報告している ${ }^{24)}$. 一方，未成熟ラット (16), 25), 26) を用いた場合でも，同様な 子宮に対するエストロゲン作用が観察されている。一般 に動物実験を実施する場合，動物への無用なストレスを 与える処置はできるだけ除くことが GLP 施行上におい ても指摘されており，著者らは，実験動物への手術スト レスが無い未成熟ラットを用いる方法を採用した。 その 結果，SM 及び被験物質は子宮重量並びに子宮及び腔粘 膜上皮細胞に対しても作用を示さず，in vivo において あエストロゲン様作用を有さないことが示唆された。

以上のことから，SM 及び本試験に用いたこれらの被 験物質は，ホルモン受容体レベル，細胞レベル及び実験 動物レベルにおいてェストロゲン様作用を有さないこと が明らかになった。また，AR 結合試験及び精巣細胞ス テロイド生合成試験の結果より，これらの被験物質がア ンドロゲン系にも作用を与えず，更に他のステロイドホ ルモン生合成系にも影響しないことから，いわゆる内分 泌撹乱作用を有さないと推察された。

\section{結論}

ポリスチレン製カップ麵容器から微量に溶出すること が確認されている SD3 検体 (NSD-01,08, 09), ST3 検 体 (NST-01,02,03) 及び SM の内分必擋乱作用の有無 をエストロゲン受容体 (ER) 結合試験, アンドロゲン受 容体 (AR) 結合試験, ヒト乳ガン細胞 MCF-7 増殖試験, ラット精巣細胞ステロイドホルモン生合成試験及び幼若 ラット子宮肥大試験により検討した。 その結果, これら の被験物質は，いずれの試験においても有意な活性を示 さなかった．以上の結果，本試験に用いた SM，SD及 びST は内分泌擋乱作用を有さないと推察された。 


\section{文献}

1) 河村葉子, 杉本直樹, 武田由比子, 山田 隆: 食衛誌. 39, 110 119 (1998).

2) 河村葉子, 河村麻衣子, 武田由比子, 山田 隆：食衛誌. 39, 199 205 (1998).

3) 河村葉子, 西 暁子, 佐々木春美, 山田 隆: 食衛誌. 39, 310 314 (1998).

4) Colborn, T., Dumanoski, D., Myers, J. P.: "Our Stolen Future" p. 253 (1996) The Penguin Group, New York.

5) The OECD Joint NCM/RAAB the Risk Working Group on Endocrine Disrupter Testing and Assessment: August 10 11 (1998).

6) Endocrine Disruptor Screening and Testing Advisory Committee (EDSTAC) : Final draft report, June 17 (1998).

7）厚生省内分泌擋乱化学物質の健康影響に関する検討会： 第 2 回議事録, 平成 10 年 5 月 27 日 (1998).

8) Corson, B. B., Heintzelman, W. J., Moe, H., Rousseau, C. R.: J. Org. Chem. 27, 1,636 1,640 (1962).

9) Okuda, Y., Yoshihara, M., Maeshima, T., Fujii, M., Aida, T.: Chem. Express 3, 459 462 (1988).

10) Holzer, G., Miller, R., Hathcock, S. L., Bertsch, W.: Polymer Bulletin 22, 421 428 (1989).

11) Kurze, V. J., Stein, D. J., Simak, P., Mosthaf, P.: Angew. Makromol. Chem. 12, 25 41 (1970).

12) Lai, S. T., Locke, D. C.: J. Chromatography 255, 511 527 (1983).

13) Gramshaw, J. W., Vandenburg, H. J., Lakin, R. A.: Food Addit. Contam. 12, 211 222 (1995).
14）山田敏広：有機合成化学協会誌 57(1), 58～64 (1999).

15) Krishnan, A. V., Stathis, P., Permuth, S. F., Tokes, L., Feldman, D.: Endocrinology 132, 2,279 2,286 (1993).

16) Dalton, J.T., Mukherjee, A., Zhu, Z., Kirkovsky, L., Miller, D. D.: Biochem. Biophys. Res. Commun. 244, $1 \sim 4$ (1998).

17) Soto, A. M., Sonnenschein, C., Chung, K. L., Fernandez, M. F., Olea, N., Serrano, F. O.: Environ. Health Perspect. 103, 113 122 (1995).

18) Klinefelter, G. R., Laskey, J. W., Roberts, N. L.: Toxicol. Appl. Pharmacol. 107, 460 471 (1991).

19) Odum. J., Lefevre, P. A., Tittensor, S., Paton, D., Routledge, E. J., Beresford, N. A., Sumpter, J. P., Ashby, J. Reg. Toxicol. Pharmacol. 25, 175 188 (1997).

20) Soto, A. M., Justicia, H., Wray, J. W., Sonnenschein, C.: Environ. Health Perspect. 92, 167 173 (1991).

21) Krishnam, A. V., Stathis, P., Permuth, S. F., Tokes, L., Feldman, D.: Endocrinology 132, 2,279 2,286 (1993).

22) Kelce, W. R., Monosson, E., Gamcsik, M. P., Laws, S. C., Gray, Jr., L. E.: Toxicol. Appl. Pharmacol. 126, 276 $\sim 285$ (1994).

23) Kan, P. B., Hirst, M. A., Feldman, D.: J. Steroid Biochem. 23, 1,023 1,029 (1985).

24) Cook, J. C., Kaplan, A. M., Davis, L. G., O'Connor, J. C.: Reg. Toxicol. Pharmacol. 26, 60 68 (1997).

25) Lee, P. C., Lee, W.: Bull. Environ. Contam. Toxicol. 57, $341 \sim 348$ (1996).

26) Ashby, J., Odum, J., Foster, J. R.: Reg. Toxicol. Pharmacol. 25, 226 231 (1997). 